\title{
EFFECT OF TRIGONELLA FOENUM GRAECUM ON ALPHA-GLUCOSIDASE AND DIPEPTIDYL PEPTIDASE-IV INHIBITORY ACTIVITY - AN IN VITRO STUDY
}

\author{
INBARAJ SD*, MUNIAPPAN M \\ Department of Pharmacology, Sree Balaji Medical College and Hospital, Bharath Institute of Higher Education and Research, Chennai, \\ Tamil Nadu, India. Email: inbaraj4@yahoo.co.in
}

Received: 01 August 2018, Revised and Accepted: 27 August 2018

\section{ABSTRACT}

Objective: The objective of this study is to find the effect of seed extract of Trigonella foenum graecum on the inhibition of $\alpha$-glucosidase and dipeptidyl peptidase-4 (DPP-4) enzyme activity by in vitro method.

Methods: Methanolic seed extract of T. foenum graecum seed was prepared and supplied by Sami Labs, Bengaluru, on request. For alpha-glucosidase inhibition assay, the following concentrations $(0,20,40,60,80$, and $100 \mu \mathrm{g} / \mathrm{ml})$ of extracts and for DPP-4 inhibition assay $(0,5,10,20,40,80$, 160 , and $320 \mathrm{~d} \mu \mathrm{g} / \mathrm{ml}$ ) concentrations were used. The absorbance was measured at 540 and $405 \mathrm{~nm}$ using multiplate reader, and the percentage of $\alpha$-glucosidase and DPP-4 enzyme inhibitory activity of extract fractions was calculated. Acarbose for alpha-glucosidase inhibition and vildagliptin for DDP-4 inhibition were used as standard drugs. The IC $_{50}$ value for alpha-glucosidase inhibition and DPP-4 inhibition was determined.

Results: The maximum alpha-glucosidase inhibitory activity of $T$. foenum graecum extract at $100 \mu \mathrm{g} / \mathrm{ml}$ was $68 \%$ (p<0.05) with $\mathrm{IC}_{50}$ value of 57.25 when compared to the acarbose (STD) of $94 \%$ with IC50 values of 42.78 . The maximum percentage of DPP-4 inhibition of $T$. foenum graecum extract at $320 \mu \mathrm{g} / \mathrm{ml}$ is $77.84 \%$ ( $\mathrm{p}<0.01$ ) with $\mathrm{IC}_{50}$ value of 52.26 when compared to the vildagliptin (STD) it is $80.15 \%$ with $\mathrm{IC}_{50}$ value of 22.98 .

Conclusion: The results of the in vitro studies show that T. foenum graecum seed extract has significant alpha-glucosidase and DPP-4 inhibition. Further in vivo and clinical studies are necessary to establish the antihyperglycemic and antidiabetic potential of T. foenum graecum seed extract for the treatment of Type 2 diabetes mellitus.

Keywords: $\alpha$-Glucosidase and dipeptidyl peptidase-4 enzyme, Trigonella foenum graecum, Type 2 diabetes.

(C) 2018 The Authors. Published by Innovare Academic Sciences Pvt Ltd. This is an open access article under the CC BY license (http://creativecommons. org/licenses/by/4. 0/) DOI: http://dx.doi.org/10.22159/ajpcr.2018.v11i10.28766

\section{INTRODUCTION}

Diabetes mellitus is a metabolic syndrome, characterized by hyperglycemia and abnormality of carbohydrate, protein, and fat metabolism due to relative or absolute insulin deficiency leading to micro- and macrovascular complications [1]. As per the International Diabetes Federation, 366 million people are suffering from diabetes, and which may increase two fold by 2030. In India alone, 40 million people are suffering from diabetes. India is going to lead the world with 60 million diabetic patients by 2025 [2]. In Type 2 diabetes mellitus, the postprandial hyperglycemia plays an important role in the progression and complications of the disease. Even though dietary management plays a vital role in the management of Type 2 diabetes, antidiabetic agents such as $\alpha$-glucosidase inhibitors play a vital role in controlling postprandial hyperglycemia [3].

In India, our diet constitutes $>75 \%$ of carbohydrates, and hence, changing the entire dietary pattern is practically not feasible. Measures which can restrict the carbohydrate absorption from gut by palatable natural products are an important area for research. Recent studies showed that natural drugs are nontoxic, safe, and less of side effects, and therefore, herbal medicines are likely to be used as primary healthcare treatment in diabetes mellitus [4]. Hence, this study is designed to evaluate the inhibitory role of edible herbal plant Trigonella foenicum graecum on $\alpha$-glucosidase and dipeptidyl peptidase-4 (DPP-4) enzyme activity. These important actions will help in reducing the carbohydrate absorption and enhancing the incretins such as GLP 1 and GIP in the control of hyperglycemia in Type 2 diabetes.

\section{Trigonella foenum-graecum (fenugreek)}

T. foenum-graecum (also known as fenugreek, locally called as methi) is widely used as spice and household medicine in India. It possesses many biological as well as pharmacological actions in reducing various ailments. Experimental studies showed that it has got hypolipidemic, anti-inflammatory, and reducing gastrointestinal diseases [5], antiinflammatory activity as local application in the form of gel [6]. Earlier animal studies suggested hypoglycemic and antihyperglycemic action of oral fenugreek seed powder in diabetic rat models [7]. Most of the studies showed antidiabetic activity and prevention of diabetic complications, but exact mechanism of action is not explored. Hence, this study is conducted to explore the important mechanism of gut absorption of glucose, i.e., alpha-glucosidase inhibition and incretinbased action, i.e., DPP-4 inhibitory action of T. foenum graecum.

\section{METHODS}

Fenugreek(T.foenum-graecum) seed extract (Fenusterols) was prepared and supplied by Sami Labs Ltd., Bengaluru, on request. Product Code 0566, BatchNo. H170111. Methanolic seed extract was prepared and supplied. The contents are steroidal saponins by gravimetry $52.04 \%$ w/w, alkaloids 0.630 and disogenin by HPLC $1.51 \%$ w/w. Physical, chemical, and microbiological testing done and certificate of analysis was issued by the Sami Labs Ltd. (www.samilabs.com). This extract was used for the two in vitro tests.

Determination of alpha-glucosidase inhibitory activity

Materials required

Phosphate buffer: 50 mM, pH 6.8.

Sodium carbonate: $0.1 \mathrm{M}$.

p-Nitrophenyl- $\alpha$-D-glucopyranoside (PNPG): $1 \mathrm{mM}$.

Sample: Extract with a range of concentrations $0-100 \mu \mathrm{g} / \mathrm{ml}$. Alpha-glucosidase: $1 \mu / \mathrm{ml}-\mathrm{SRL}$. 


\section{Procedure}

Alpha-glucosidase inhibitory activity of T. foenum-graecum extracts was carried out according to the method of Bachhawat et al. with slight modification [8]. Reaction mixture containing $50 \mu \mathrm{l}$ phosphate buffer, $10 \mu \mathrm{l}$ alpha-glucosidase, and $20 \mu \mathrm{l}$ of varying concentrations of extracts was pre-incubated at $37^{\circ} \mathrm{C}$ for $15 \mathrm{~min}$. Then, $20 \mu \mathrm{PNPG}$ was added as a substrate and incubated further at $37^{\circ} \mathrm{C}$ for $30 \mathrm{~min}$. The reaction was stopped by adding $50 \mu \mathrm{l}$ sodium carbonate. The yellow color produced was read at $405 \mathrm{~nm}$. Each experiment was performed along with appropriate blanks. Acarbose at various concentrations $(0-100 \mu \mathrm{g} / \mathrm{ml})$ was included as a standard. Negative control without extracts was set up in parallel. The result is expressed as percentage inhibition.

\section{Calculation}

Inhibition $(\%)=$ Abs. control - Abs. sample/Abs. control $\times 100$.

\section{DPP4 inhibitory in vitro assay}

DPP4, also known as CD26 and adenosine deaminase complexing protein 2, is a serine exopeptidase that cleaves X-Proline and X-Alanine residues from the $\mathrm{N}$-termini of polypeptides. DPP4 is a transmembrane glycoprotein whose activity regulates the bioactivity of multiple peptides such as growth factors, chemokines, and neuropeptides. DPP4 plays a major role in glucose metabolism through the regulation of glucagon-like peptide-1, and inhibitors of DPP4 are commonly used for the treatment of Type 2 diabetes [9]. DPP4 also plays an important role in immune regulation and may play a role in tumor suppression. In this assay, DPP4 cleaves a non-fluorescent substrate, H-Gly-Pro-7-amino-4-methyl coumarin (AMC), to release a fluorescent product, $\mathrm{AMC}(\mathrm{lex}=360 / \mathrm{lem}=$ $460 \mathrm{~nm}$ ). One unit of DPP4 is the amount of enzyme that will hydrolyze the DPP4substrate to yield $1.0 \mathrm{~m}$ mole of AMC per minute at $37^{\circ} \mathrm{C}[10]$.

\section{Methods and materials}

- $\quad$ DPP4 Assay Buffer $25 \mathrm{ml}$ (Catalog Number MAK088A)

- DPP4 Substrate, H-Gly-Pro-AMC 0.2 ml (Catalog Number MAK088B)

- DPP4 Positive Control $20 \mathrm{ml}$ (Catalog Number MAK088C)

- $\quad$ AMC Standard, 1 mM $0.1 \mathrm{ml}$ Catalog Number MAK088D

- DPP4 Inhibitor, Vildagliptin $1 \mathrm{ml}$.

\section{Procedure}

All samples and standards should be run in duplicate. AMC standards for fluorometric detection. Dilute $10 \mathrm{ml}$ of the $1 \mathrm{mM}$ AMC standard solution with $990 \mathrm{ml}$ of water to prepare a $10 \mathrm{mM}(10 \mathrm{p} \mathrm{mole} / \mathrm{ml})$ standard solution. Add $0,2,4,6,8$, and $10 \mathrm{ml}$ of the $10 \mathrm{mM}$ standard solution into a 96-well plate, generating 0 (blank), 20, 40, 60, 80, and $100 \mathrm{p}$ mole/well standards. Add DPP4 Assay Buffer to each well to bring the volume to $100 \mathrm{ml}$.

\section{Sample preparation}

Samples can be directly added to the wells. A sample blank is required for each test sample. Prepare a duplicate well for each sample to be used as the sample blank. Bring test samples and sample blanks to a final volume of $50 \mathrm{ml}$ with DPP4 assay buffer. For the positive control, add $1-2 \mathrm{ml}$ of the DPP4 positive control solution to wells and adjust to $50 \mathrm{ml}$ with the DPP4 assay buffer.

\section{Assay reaction}

1. Add $10 \mathrm{ml}$ of the DPP4 assay buffer to each of the sample wells. Add $10 \mathrm{ml}$ of the DPP4 inhibitor to each of the sample blank wells. Mix well by pipetting, and incubate for $10 \mathrm{~min}$ at $37^{\circ} \mathrm{C}$.

2. Set up the Master Reaction Mix according to the scheme in Table $1.40 \mathrm{ml}$ of the Master Reaction Mix is required for each sample and sample blank well. Do not add the Master Reaction Mix to the standard curve wells.

\section{Reagent volume}

1. Add $40 \mathrm{ml}$ of the Master Reaction Mix to each of the wells. Mix well by pipetting. Cover the plate and protect from light during the incubation.
2. Incubate the plate at $37^{\circ} \mathrm{C}$. After $5 \mathrm{~min}$, take the initial measurement ( $\mathrm{T}$ initial). Measure the fluorescence intensity (FLU) initial, lex $=360$ / lem $=460 \mathrm{~nm}$ ).

3. Note: It is essential (FLU), initial is in the linear range of the standard curve.

4. Continue to incubate the plate at $37^{\circ} \mathrm{C}$ taking measurements (FLU) every $5 \mathrm{~min}$. Protect the plate from light during the incubation.

5. Continue taking measurements until the value of the most active sample is greater than the value of the highest standard (100 p mole/ well). At this time, the most active sample is near or exceeds the end of the linear range of the standard curve.

6. The final measurement (FLU final) for calculating the enzyme activity would be penultimate reading or the value before the most active sample is near or exceeds the end of the linear range of the standard curve, as shown in step 5 . The time of the penultimate reading is $\mathrm{T}$ final.

\section{Calculations}

Corrected for the background by subtracting the final measurement ([FLU] final) obtained for the 0 (blank) AMC standard from the final measurement ([FLU] final) of these standard and samples. Background values can be significant and must be subtracted from all readings. Plot the standard curve.

Note: A new standard curve must be set up each time the assay is run.

Calculate the change in measurement from $\mathrm{T}$ initial to $\mathrm{T}$ final for the samples.

$D F L U=(F L U)$ final $-(F L U)$ initial

Furthermore, subtract the sample blank D measurement value from the sample D measurement values. Compare the DFLU of each sample to the standard curve to determine the amount of AMC released by the DPP4 assay between $\mathrm{T}$ initial and $\mathrm{T}$ final (B).

The DPP4 activity of a sample may be determined by the following equation:

DPP4 Activity $=\mathrm{B} \times$ Sample dilution factor $/($ Reaction time $) \times \mathrm{V}$

$\mathrm{B}=$ Amount ( $\mathrm{p}$ mole) of AMC released between $\mathrm{T}$ initial and $\mathrm{T}$ final

Reaction time $=\mathrm{T}$ final $-\mathrm{T}$ initial $(\mathrm{min})$

$\mathrm{V}=$ Sample volume $(\mathrm{ml})$ added to well

DPP4 activity is reported as $\mathrm{p}$ mole $/ \mathrm{min} / \mathrm{ml}=$ micro unit $/ \mathrm{ml}$

One unit of DPP4 is the amount of enzyme that will hydrolyze the DPP4 substrate to yield $1.0 \mathrm{~m}$ mole of AMC per minute at $37^{\circ} \mathrm{C}$.

\section{Statistical analysis}

The collected data from the observations were analysed by descriptive statistics such as mean, standard deviation, standard error and \% of inhibition [11]. The statistical analysis was performed using Microsoft Excel program 2013.

\section{RESULTS AND DISCUSSION}

\section{Alpha-glucosidase enzyme inhibitory action}

This in vitro study shows that maximum alpha-glucosidase inhibition of T. foenum-graecum at $100 \mu \mathrm{g} / \mathrm{ml}$ is $68 \%(\mathrm{p}<0.05)$ with IC $_{50}$ value of 57.25 when compared to the acarbose (STD) of $94 \%$ with IC $_{50}$ values of 42.78 (Table 2 and Fig. 1).

This activity confirms the action of T. foenum-graecum on in vitro alpha-glucosidase inhibitory potential by the similar study [12] Another similar study which evaluated the antidiabetic potential of

\section{Table 1: Master reaction mix}

\begin{tabular}{ll}
\hline DPP4 Assay Buffer $38 \mathrm{ml}$ & DPP4 substrate $2 \mathrm{ml}$ \\
\hline
\end{tabular}


Table 2: Percentage inhibitory activity of Fenugreek (Trigonella Foenum-graecum) seed extract on alpha-glucosidase enzyme activity in comparison with Acarbose ( $n=6)$

\begin{tabular}{|c|c|c|c|c|}
\hline Concentrations of sample $(\mu \mathrm{g} / \mathrm{ml})$ & Mean \pm SD $(n=6)$ & $\%$ Inhibition of fenugreek & Mean $\pm S D(n=6)$ & $\%$ Inhibition of Acarbose \\
\hline 0 & $0.713 \pm 0.0024$ & 0.22 & $0.73 \pm 0.0024$ & 0.22 \\
\hline 20 & $0.734 \pm 0.007$ & 25 & $0.510 \pm 0.006$ & 45 \\
\hline 40 & $0.621 \pm 0.011$ & 34 & $0.410 \pm 0.002$ & 57 \\
\hline 60 & $0.510 \pm 0.006$ & 45 & $0.301 \pm 0.001$ & 68 \\
\hline 80 & $0.412 \pm 0.002$ & $56^{*}$ & $0.135 \pm 0.009$ & 84 \\
\hline 100 & $0.301 \pm 0.001$ & $68^{*}$ & $0.124 \pm 0.020$ & 94 \\
\hline
\end{tabular}

Values are mean $\pm \mathrm{SD} ;(\mathrm{n}=6){ }^{*} \mathrm{p}<0.05$ when compared to Acarbose

Table 3: Percentage inhibitory activity of (Trigonella foenum-graecum) on dipeptidyl peptidase-IV enzyme in comparison with vildagliptin (n=8)

\begin{tabular}{|c|c|c|c|c|}
\hline Concentrations of sample $(\mu \mathrm{g} / \mathrm{ml})$ & Mean \pm SD $(n=8)$ & $\%$ Inhibition of fenugreek & Mean \pm SD $(n=8)$ & $\%$ Inhibition of vildagliptin \\
\hline 0 & $0.715 \pm 0.005$ & 0.66 & $0.952 \pm 0.0058$ & 0.66 \\
\hline 5 & $0.687 \pm 0.006$ & 4.52 & $0.826 \pm 0.0052$ & 13.66 \\
\hline 10 & $0.680 \pm 0.004$ & 4.41 & $0.710 \pm 0.0030$ & 25.32 \\
\hline 20 & $0.594 \pm 0.006$ & 17.44 & $0.602 \pm 0.0119$ & 36.13 \\
\hline 40 & $537 \pm 0.007$ & 25.21 & $0.480 \pm 0.0072$ & 48.63 \\
\hline 80 & $0.309 \pm 0.006$ & 56.83 & $0.326 \pm 0.0096$ & 66.18 \\
\hline 160 & $0.293 \pm 0.010$ & 59.85 & $0.260 \pm 0.0070$ & 73.32 \\
\hline
\end{tabular}

Values are mean $\pm \mathrm{SD} ;(\mathrm{n}=8){ }^{*} \mathrm{p}<0.01$ when compared to vildagliptin

phytoconstituents such as alkaloids, peptidoglycans, saponins, guar gum, pectins, glycosides and their mode of action on metabolic pathway. It also confirmed that $T$. foenum-graecum has antihyperglycemic action by interfering with carbohydrate absorption and digestion [14]. T. foenum-gracum an important dietary ingredient which may be developed into an important antidiabetic medication to control the post prandial blood glocose.

\section{DPP-4 ENZYME INHIBITORY ACTION}

The maximum percentage of DPP-4 inhibition of $T$. foenum graecum extract at $320 \mu \mathrm{g} / \mathrm{ml}$ is $77.84 \%(\mathrm{p}<0.01)$ with $\mathrm{IC}_{50}$ value of 52.26 when compared to the vildagliptin (STD) is $80.15 \%$ with IC 50 value of 22.98 . (Refer Table 3 and Fig. 2).

A similar research study evaluated the Indonesian herbs for in vitro DPP4 inhibition [15]. In that study, Klabet (Indonesia) (T. foenum-graecum) showed $72.29 \%$ DPP-4 inhibition, whereas our study showed 77.84\% DPP4 inhibition at highest concentration. This confirms that T. foenum graecum possesses a significant DPP-4 inhibition potential and it could be a promising drug target for edible herbal-based DPP-4 inhibitor. A meta-analysis of clinical trials done on the effect of fenugreek (T. foenum graecum) intake on glycemia [16] clearly concluded that fenugreek seeds have beneficial effects on glycemic control in diabetic patients. Enhancement of antidiabetic activity by T. foenum-graecum (4-hydroxyisoleucine) was demonstrated by a animal study [17] which again confirms the antidiabetic potential of the study extract. However, more clinical studies with well-characterized fenugreek preparations are needed for human use. Many such articles even stressed the importance of $T$. foenum graecum to be included in the drug therapy for the prevention and management of diabetes.

\section{CONCLUSION}

The in vitro studies showed that seed extract of T. foenum graecum has significant alpha-glucosidase and DPP-4 inhibition activity. Further in vivo and clinical studies are necessary to establish the antihyperglycemic and antidiabetic potential of $T$. foenum graecum for the treatment of Type 2 diabetes mellitus.

\section{ACKNOWLEDGMENT}

The authors wouuuld like to thank Prof. M.Muniappan, Professor of Pharmacology, Sree Balaji Medical College and Hospital, BIHER,

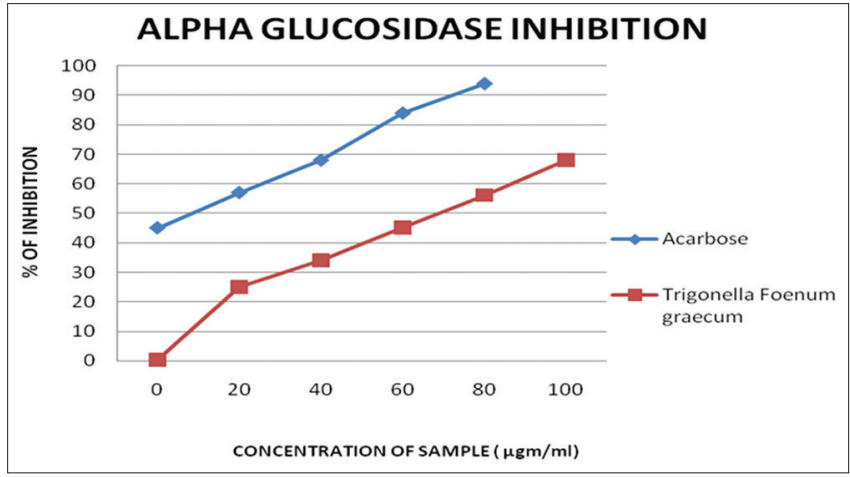

Fig. 1: Percentage inhibitory activity of Fenugreek (Trigonella foenum-graecum) seed extract on alpha-glucosidase enzyme in comparison with acarbose

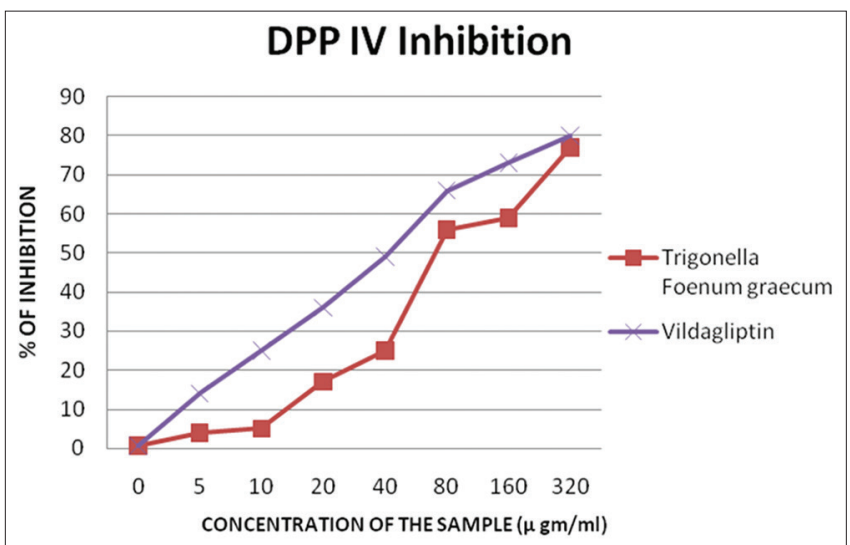

Fig. 2: Percentage inhibitory activity of Trigonella foenumgraecum on dipeptidyl peptidase-IV enzyme in comparison with Vildagliptin

for guiding us to undertake the research. We gratefully acknowledge Sami Labs Ltd., Bengaluru, for supplying the extracts free of cost and encouraged me to do research. 


\section{AUTHORS' CONTRIBUTIONS}

Both the authors contributed substantially for the research work presented in the manuscript.

\section{CONFLICTS OF INTEREST}

There are no conflicts of interest for the above study.

\section{REFERENCES}

1. Alberti KG, Zimmet PZ. Definition, diagnosis and classification of diabetes mellitus and its complications. Part 1: Diagnosis and classification of diabetes mellitus provisional report of a WHO consultation. Diabet Med 1998;15:539-53.

2. King H, Aubert RE, Herman WH. Global burden of diabetes, 19952025: Prevalence, numerical estimates, and projections. Diabetes Care 1998;21:1414-31.

3. Ceriello A. Point: Postprandial glucose levels are a clinically important treatment target. Diabetes Care 2010;33:1905-7.

4. Sharma H, Chandola HM, Singh G, Basisht G. Utilization of ayurveda in health care: An approach for prevention, health promotion, and treatment of disease. Part 2 - Ayurveda in primary health care. J Altern Complement Med 2007;13:1135-50.

5. Grover JK, Yadav S, Vats V. Medicinal plants of India with anti-diabetic potential. J Ethnopharmacol 2002;81:81-100.

6. Jyothi D, Koland M. Formulation and evaluation of an herbal antiinflammatory gel containing Trigonella foenum greacum seed extract. Int J Pharm Pharm Sci 2016;8:41-4.

7. Hannan JM, Rokeya B, Faruque O, Nahar N, Mosihuzzaman M, Azad Khan AK, et al. Effect of soluble dietary fibre fraction of Trigonella foenum graecum on glycemic, insulinemic, lipidemic and platelet aggregation status of type 2 diabetic model rats. J Ethnopharmacol 2003;88:73-7.

8. Bachhawat JA, Shihabudeen MS, Thirumurugan K. Screening of fifteen Indian ayurvedic plants for alpha-glucosidase inhibitory activity and enzyme kinetics. Int J Pharm Pharm Sci 2011;3:267-74.

9. Avogaro A, Fadini GP. The effects of dipeptidyl peptidase-4 inhibition on microvascular diabetes complications. Diabetes Care 2014;37:2884-94.

10. Ghate M, Jain SV. Structure based lead optimization approach in discovery of selective DPP4 inhibitors. Mini Rev Med Chem 2013;13:888-914.

11. Lekshmi PC, Arimboor R, Nisha VM, Menon AN, Raghu KG. In vitro antidiabetic and inhibitory potential of turmeric (Curcuma longa $\mathrm{L}$ ) rhizome against cellular and LDL oxidation and angiotensin converting enzyme. J Food Sci Technol 2014;51:3910-7.

12. Hui H, Tang G, Go VL. Hypoglycemic herbs and their action mechanisms. Chin Med 2009; 4:11.

13. Bharti SK, Krishnan S, Kumar A, Kumar A. Antidiabetic phytoconstituents and their mode of action on metabolic pathways. Ther Adv Endocrinol Metab 2018;9:81-100.

14. Khosla P, Gupta DD, Nagpal RK. Effect of Trigonella foenum graecum on serum lipids in normal and diabetic rats. Indian J Physiol Pharmacol 1995;27:89-93.

15. Riyanti S, Suganda AG, Sukandar EY. Dipeptidyl peptidase-IV inhibitory activity of some Indonesian medicinal plants. Asian J Pharm Clin Res 2016;9:375-7.

16. Neelakantan N, Narayanan M, de Souza RJ, van Dam RM. Effect of fenugreek (Trigonella foenum-graecum L.) intake on glycemia: A metaanalysis of clinical trials. Nutr J 2014;13:7.

17. Shukla P, Rangari V. Enhancement of anti diabetic activity of 4- hydroxyisoleucine in combination with natural bioavailability enhancers. Int J Pharm Pharm Sci 2015;7:302-6. 